\title{
Educational Philosophy and Theory
}

\section{At the wake, or the return of metaphysics}

\section{Johan Dahlbeck}

To cite this article: Johan Dahlbeck (2018) At the wake, or the return of metaphysics, Educational Philosophy and Theory, 50:14, 1462-1463, DOI: 10.1080/00131857.2018.1458783

To link to this article: https://doi.org/10.1080/00131857.2018.1458783

(C) 2018 The Author(s). Published by Informa
UK Limited, trading as Taylor \& Francis
Group




\title{
At the wake, or the return of metaphysics
}

\author{
Johan Dahlbeck
}

Faculty of Education and Society, Malmö University, Malmö, Sweden

We have all been told of the death of grand narratives. We have been told that the days of asking eternal metaphysical questions in philosophy are long since over. When Wittgenstein's (1953/2009, p. 174) famous spade hit bedrock it reminded us that we had better stop wasting our time on lofty questions without answers. Foucault (1970) prompted us to recall Borges' story of a certain Chinese encyclopedia showing us that there are many ways of ordering the world and that each way changes the rules of the game a little bit. We found that history was contingent and that hierarchies, however firmly built, would all crumble in the end. In its place were the slightly disorienting feeling following the postmodernist's proclamation of 'the elusiveness of meaning and knowledge' (Kirby, 2017, p. 5).

Echoes of the past still haunt us however. It turned out that the metaphysical questions of old were not so easily abandoned after all. While we might turn a blind eye to them, we are still bound to them by our tacit presuppositions and they still tend to lurk in the shadow of our every endeavor to rethink the old. What's dead and buried can sometimes return. Educational philosophy is in need of a direction as it is always aimed at some kind of change. Metaphysical assumptions can provide us with a direction. If we assume a capacity of free will, education can achieve certain ends, and if we assume that free will is a myth then education needs to abandon certain claims and stake out new paths. Both assumptions may be valid but they will result in very different understandings of what education is and what it can achieve. We may never be able to answer the question of whether free will exists or not, but we will always base our theories of education on assumptions about our agential capacity. Metaphysics follows us even when we try our best to outrun it.

While the door opened by the postmodern skepticism of eternal truths cannot be closed, it may be that we can benefit from acknowledging our need for addressing our most basic metaphysical assumptions without unlearning the lesson of postmodernism. Like Foucault's encounter with the Chinese encyclopedia, we might find joy in revisiting the lost traditions of the past without assuming that they can salvage us from the perils of our future. The postmodern doubt not only shook things up, but it helped us see that we always rely on something, whether we know it or not. Rather than tear down the great structure of metaphysics once and for all, it helped reveal that the questions we ask always betray some kind of metaphysical assumption. Seeing this, we can return to the great metaphysical questions a little less innocent than before. We can come to terms with the fact that we have no choice but to continue asking the same old questions. Not because we will ever find the final answer some day, but because our different ways of answering them will continue to shape how we live.

\section{Disclosure statement}

No potential conflict of interest was reported by the author. 


\section{Notes on contributor}

Johan Dahlbeck is an associate professor of Education at Malmö University in Sweden. His research interest is in the philosophy of education. The authors recent publications include the book'Spinoza and Education: Freedom, Understanding and Empowerment' (Routledge, 2016). Currently, Dahlbeck is finalizing a research monograph titled 'Education and Free Will: Spinoza, Causal Determinism and Moral Formation' (Routledge, forthcoming).

\section{ORCID}

Johan Dahlbeck iD http://orcid.org/0000-0003-1669-7132

\section{References}

Foucault, M. (1970). The order of things. New York, NY: Pantheon Books.

Kirby, A. (2017). The death of postmodernism and beyond. Philosophy Now, (121). Retrieved from https://philosophynow. org/issues/58/The_Death_of_Postmodernism_And_Beyond

Wittgenstein, L. (1953/2009). Philosophical investigations (rev. 4th ed.). Chichester: Wiley-Blackwell. 